\title{
VTR シリンダー用アルミニウム合金の諸特性
}

\author{
浅野 和彦*・宮上晃*・有井 泰隆*
}

Properties of aluminum alloys for VTR cylinder

Kazuhiko ASANO, Akira MIYAGAMI and Yasutaka ARII

\section{1. はじめに}

近年，VTR 市場の急激な拡大が注目を集めている。 図 1 はVTR の生産台数の推移を示すが，1975年以降ほ ぼ指数関数に近い形で増加していることがわかる。'82 年に 1,000 万台をはじめて越えたが，その 2 年後の' 84 年には早くも2,500万台が見込まれるに至つている。 VTR の大半は輸出されており，日本国内での普及率は $30 \%$ 程度なので, VTR 市場の伸びは当面続くものと考 えられる。

周知のよらに，VTR には記録・再生用の磁気ヘッド を組込んだシリンダーやディスクが搭載されており，こ れがアルミニウム合金製であるため，VTR の市場は同 時にアルミニウム合金の市場でもある。VTR シリンダ 一の単体重量はメーカーや機種によつても異なるが，年 間 2,500 万台の生産とすると 5,000 トン/年を越える 規模 と見積られている。

VTR シリンダー用の材料としてはこれまで多くのも のが検討されてきた。開発当初は陽極酸化処理を施した アルミニウム鋳物，硬質クロムメッキした銅合金，オー ステナイト系ステンレス鋼などが使用された。その後 AC5A, AC8A, AC8B などのアルミニウムが使われた が，ピンホールや巣などの鋳造欠陥が問題となつた。現 在の家庭用カセットVTR のシリンダーは一部の鋳物と 2218 (Al-Cu-Mg-Ni系) 合金の鋳造棒または押出棒から の冷間鍛造品が多い。

シリンダー用の新しい合金も素材メーカーを主体に開 発が進められているが1)，その詳細はほとんど公表され ていない。本稿の目的はVTR シリンダー用アルミニウ ム合金の紹介であるが，上述の事情にかんがみ，現在市 場で一般的に入手できる材料に限定してその特性をまと めてみた。

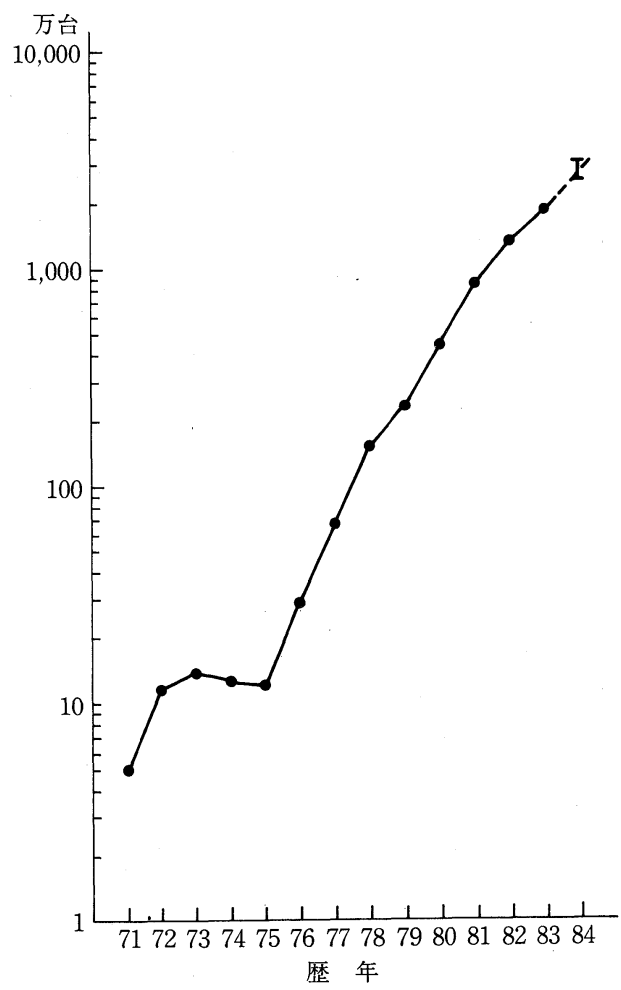

図 1 VTR の生産台数の推移

\section{2. 磁気テープの構造と走行機構}

VTR シリンダー材の特性をみるに先だつて, 磁気テ 一プの構造とその走行機構をみておくことにしよう。そ れらがシリンダー材として要求される特性を大きく支配 しているからである。

衆知のように, VTR は磁気テープに磁気ヘッドを接 触させて映像と音声を磁気パターンとして記録する装置 
である。その心臓部は回転磁気へッド部と磁気テープを 安定に走行させるための案内ドラムから構成されてい る。家庭用 VTR には，1975年 5 月ソニーが開発したB マックス方式と1976年 9 月日本ビクターが発表した VH $\mathrm{S}$ 方式の 2 種があり，シリンダーの構造および走行機構 にじゃっかんのちがいがある。

図 2 はVHS 方式のテープ走行系を示す2)。この方式 では磁気ヘッドを組み込んだ上部回転シリンダーと下部 固定シリンダー系を採用している。下部シリンダーには 写真 1 に示すように斜めのテープガイドがあり, テープ はこのガイドの下縁を基準として走行する。上部シリン ダーを回転させることによりテープとシリンダーの間に エアギャップを発生させ, テープの走行安定性を保つ工 夫がなされている。

$\beta$ マックス方式ではシリンダー系は上部固定シリンダ 一, 回転ヘッドディスク, 下部固定シリンダーから構成 されている。この場合にもテープは下部シリンダーのガ イドに沿つて走行することになつている (図 $3^{22}$ )。

一方ビデオテープの多くはベース（ポリエステル）上 にバインダーを介して粉末の磁性体を塗布した構造にな つている。写真 2 に市販の $1 / 2$ インテープの表面状態を

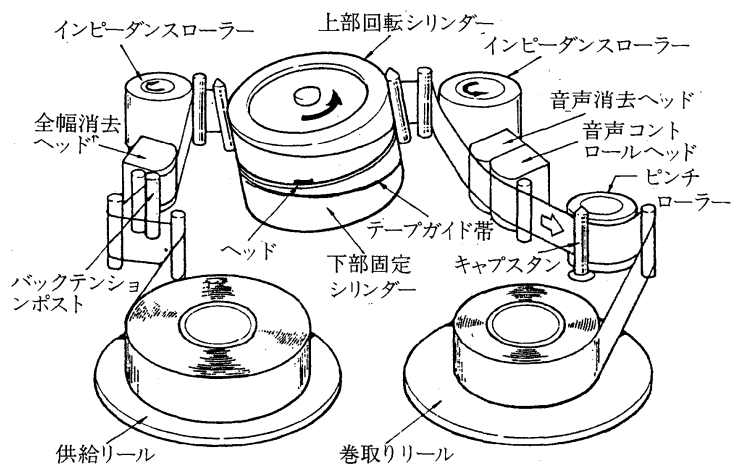

図 2 VHS 方式におけるテープ走行系 (原 ${ }^{2)}$ による)

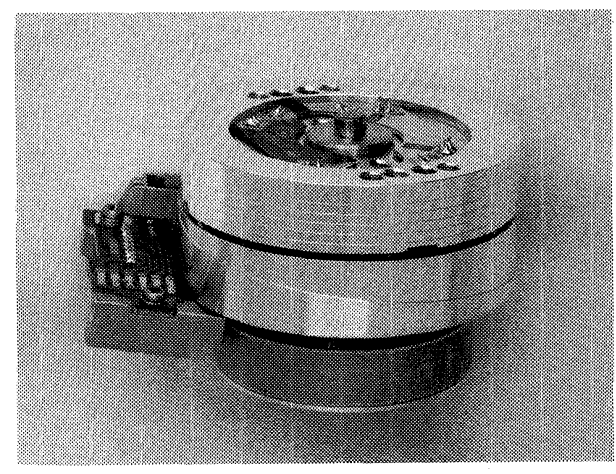

写真 1 VHS 方式の VTR シリンダー
示す。メーカーにより磁性体がバインダー中に埋没して いるものから表面に多量に露出しているものまで各種の テープが市販されている。

磁性体は酸化物であり，一般に硬度が高い。この酸化 物がシリンダー上を摺動するため，シリンダー材には耐 摩耗性が必要とされることになるのである。

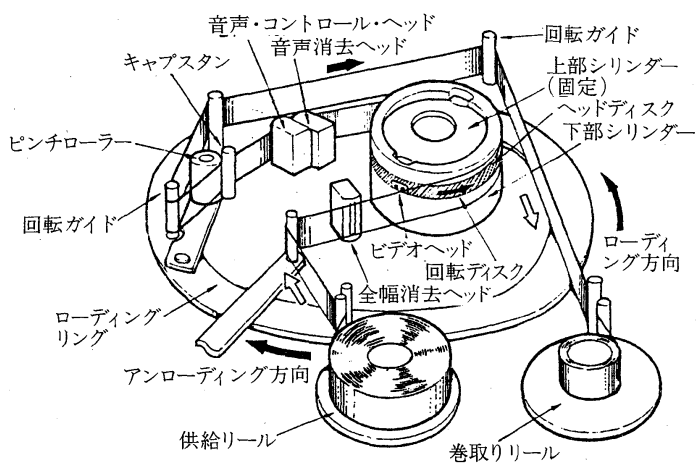

図 $3 \beta$ マックス方式におけるテープ走行系 (原 ${ }^{2)}$ による)

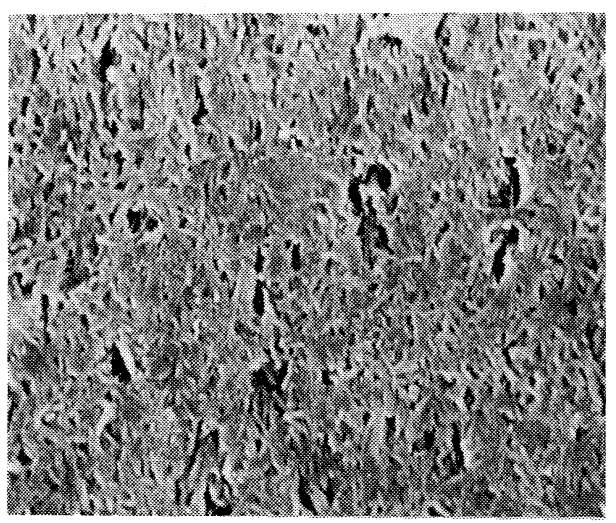

$A$ 社製

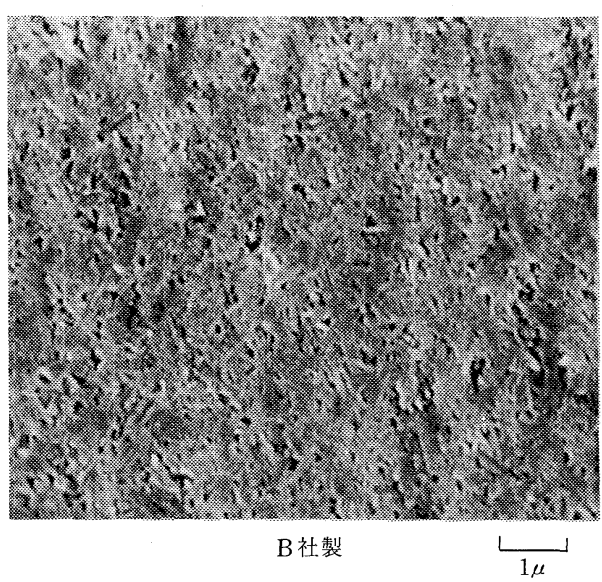

写真 2 市販 VTR テープの表面状況 


\section{3. シリンダー用合金の一般的特性}

代表的な VTR シリンダー用アルミニウム合金の組成 を表 1 に示す。いずれも $\mathrm{Al}-\mathrm{Cu}-\mathrm{Mg}-\mathrm{Ni}$ をベースとし， 鋳物はそれに Si を添加しているものが多い。Niを含有 しているのが他の一般的アルミニウム合金と異なる共通 の特徵である。元来, $\mathrm{Ni}$ は耐熱性を高める元素として 添加されるが，シリンダーの場合にはむしろ耐摩耗性を 高める効果があると考えられる。鋳物における Si は溶 湯の流動性を良くするために添加されるが，これもシリ ンダーでは耐摩耗性を向上させる。

表 2 にそれらの合金の機械的性質を示す。鋳物 (T6) では引張り強さが約 $30 \mathrm{kgf} / \mathrm{mm}^{2}$ 以上である。2218は T6 としての規格は定められておらず，T72 調質での標準值 として引張り強さ $34 \mathrm{kgf} / \mathrm{mm}^{2}$, 耐力 $26 \mathrm{kgf} / \mathrm{mm}^{2}$, 伸び12 \%が示されているだけである3”。2218製のシリンダーは 冷間鍛造後, T6 処理されるが, 押出材 $(\mathrm{T} 6)$ では引張り 強さ $40 \mathrm{kgf} / \mathrm{mm}^{2}$, 耐力 $35 \mathrm{kgf} / \mathrm{mm}^{2}$, 伸び $12 \%$ 程度であ る。

いずれの合金む，多かれ少なかれ $\mathrm{Cu}$ を含んでいるの で耐食性がいいとは言い難い。シリンダーは一般に切削 のまま使用され，表面処理しないことが多いのでこの点 ではやや問題がある。しかし VTR の使用環境は腐食と いら面ではマイルドであることが普通なので，実際上腐 食が問題となることはあまりない。まれに，長時間休止 中に結露等で水滴が付着して腐食するといら例がある。 その意味でも耐食性の向上はVTR シリンダー材として のひとつの課題といえよう。

写真 3 に2218および AC8A の鋳造組織（熱処理後）を 示す。2218では主として $\mathrm{Al}_{3} \mathrm{Ni}$ の化合物が全面に晶出 しているが，EPMA 分析によるとこの化合物中には $\mathrm{Cu}$
も共存している。 $\mathrm{Al}_{3} \mathrm{Ni}$ 中の $\mathrm{Ni}$ の一部が $\mathrm{Cu}$ と置換し たものと考えられる。一方 AC8A では針状の共晶 Si と $\mathrm{Al}_{3}(\mathrm{Ni}, \mathrm{Cu})$ とが共存している。これらの初晶 $\mathrm{Si}$ $\mathrm{Al}_{3}(\mathrm{Ni}, \mathrm{Cu})$ 化合物が耐摩耗性を高める。また熱処理に よつて生成される析出物も耐摩耗性向上に寄与する。

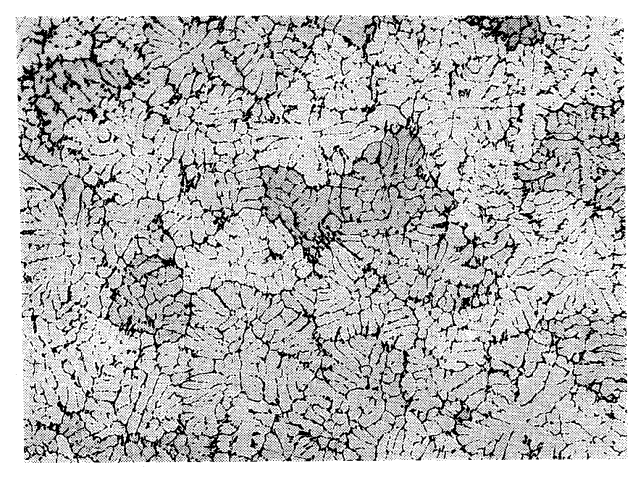

2218

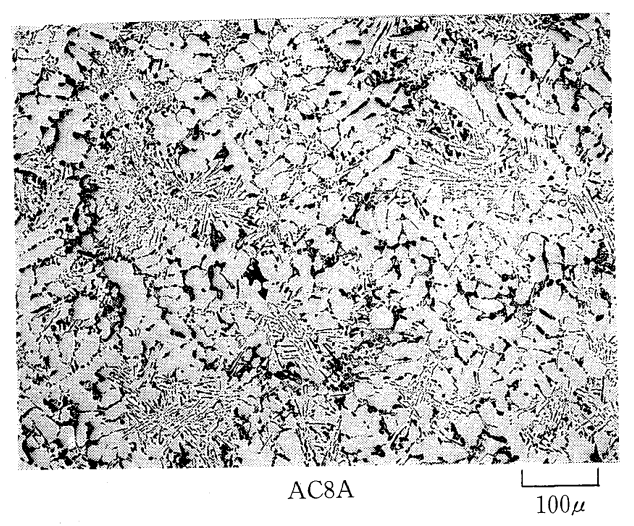

写真 3 代表的シリンダー材の光学顕微鏡組織

表 1 代表的シリンダー用アルミニウム合金の化学成分 (wt\%)

\begin{tabular}{|c|c|c|c|c|c|c|c|c|c|}
\hline 品種 成分 & $\mathrm{Si}$ & $\mathrm{Fe}$ & $\mathrm{Cu}$ & $\mathrm{Mn}$ & $\mathrm{Mg}$ & $\mathrm{Zn}$ & $\mathrm{Cr}$ & $\mathrm{Ti}$ & その他 \\
\hline 2218 & $\leq 0.9$ & $\leq 1.0$ & $3.5 \sim 4.5$ & $\leq 0.20$ & $1.2 \sim 1.8$ & $\leq 0.25$ & $\leq 0.10$ & - & Ni $1.7 \sim 2.3$ \\
\hline AC5A & $\leq 0.6$ & $\leq 0.8$ & $3.5 \sim 4.5$ & $\leq 0.30$ & $1.2 \sim 1.8$ & $\leq 0.10$ & - & $\leq 0.20$ & Ni $1.7 \sim 2.3$ \\
\hline AC8A & $11 \sim 13$ & $\leq 0.8$ & $0.8 \sim 1.3$ & $\leq 0.10$ & $0.7 \sim 1.3$ & $\leq 0.10$ & - & $\leq 0.20$ & Ni $0.8 \sim 1.5$ \\
\hline $\mathrm{AC} 8 \mathrm{~B}$ & $8.5 \sim 10.5$ & $\leq 1.0$ & $2.0 \sim 4.0$ & $\leq 0.50$ & $0.5 \sim 1.5$ & $\leq 0.50$ & 一 & $\leq 0.20$ & $\mathrm{Ni} \leq 1.0$ \\
\hline
\end{tabular}

表 2 代表的シリンダー用アルミニウム合金の機械的性質

\begin{tabular}{l|c|c|c|c|c}
\hline \hline & $\begin{array}{c}\text { 引 張 強さ } \\
\left(\mathrm{kgf} / \mathrm{mm}^{2}\right)\end{array}$ & $\begin{array}{c}\text { 恧 } \\
\left(\mathrm{kgf} / \mathrm{mm}^{2}\right)\end{array}$ & $\begin{array}{c}\text { 伸 } \\
(\%)\end{array}$ & ブリネル硬さ & 備 \\
\hline 2218-T72 & 33.5 & 26.0 & 11 & 95 & 考 \\
AC5A-T6 & $\geq 30$ & - & - & 約 110 & 金型鋳 物 \\
AC8A-T6 & $\geq 28$ & - & - & 約 110 & 同 \\
AC8B-T6 & $\geq 28$ & - & 約 110 & 上 \\
\hline
\end{tabular}




\section{VTR シリンダー材として要求される諸 特性}

シリンダー材に要求される特性はVHS 方式と $\beta$ マッ クス方式とでじやつかん異なるし，それぞれの特性の重 要度もテープの構造などでかわつてくる。ここではごく 一般的な特性をみてみる。代表的な特性としては以下の ものがあげられる。

\section{(1) 非磁性体であること}

VTR は磁気記録方式の装置であるから，テープと接 触するシリンダーは当然非磁性でなければならない。シ リンダー材としてアルミニウム合金が選ばれる基本的な 理由もここにあり，開発当初使われた銅合金やオーステ ナイト系ステンレスも同様である。

\section{(2) 耐摩耗性}

すでに述べたように，シリンダー表面は硬い磁性粉を 塗布したテープが摺動するので摩耗の生じる危険が常に ある。写真 4 は2218の円筒試験片に磁気テープを摺動さ せて人為的に摩耗させたものの表面状態である。試験前 には切削の送りマークが明膫に認められるのに対して, 試験後には表面が荒れていることがわかる。現実にはシ リンダーよりる磁気ヘッドの摩耗の方がより重要な問題 であり，写真 4 のよな現象はまず生じないし，また VHS 方式ではシリンダーとテープの間に薄い空気の膜 (エアギャップ) が形成され，テープが直接接触しない ようになつている。しかし VTR の小型化や記録密度の 高度化に伴つてェアギャップも小さくなる傾向にあり， シリンダーの摩耗もより重要な問題になつてきている。 特に，テープガイドの下縁部はテープ端面と接触するた め最も摩耗しやすいといわれている。この部分が摩耗す るとテープの走行位置がずれ，トラッキングエラーを生 じるため, $1 \mu$ の摩耗でも影響が出る ${ }^{2)} 。$

VTR テープによるアルミニウム合金の摩耗挙動につ いては多くのことは公表されていない。江田 ${ }^{4)}$ は，礎気 テープの耐摩耗性が FC 30 と同程度であることを利用し て，FC 30を相手材とする大越式試験法でシリンダー材 の耐摩耗性を調べている。図 4 はその結果である。それ によれば耐摩耗性は AC8B>4032>2218>AC5A の順 になる。この結果から江田は $\mathrm{Si}, \mathrm{Cu}$ の含有量が高いほ ど耐摩耗性が向上するとしている。

耐摩耗性に関連した大きな問題点はその評価方法が確 立していないことであろう。江田が採用した大越式試験 法は迅速測定法としては簡便で良いが，これがテープに よる実際の摩耗をシミュレートしているかどらかは確認 される必要がある。耐摩耗性の評価方法は $8 \mathrm{~mm} \mathrm{VTR}$ やメタルテープの普及とともにますます重要性を増すも のと予測されるだけに，その確立が急務であろら。

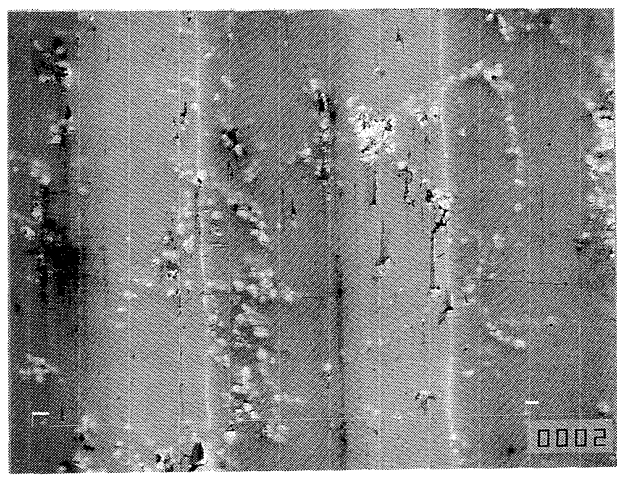

$$
\text { テスト前 }
$$

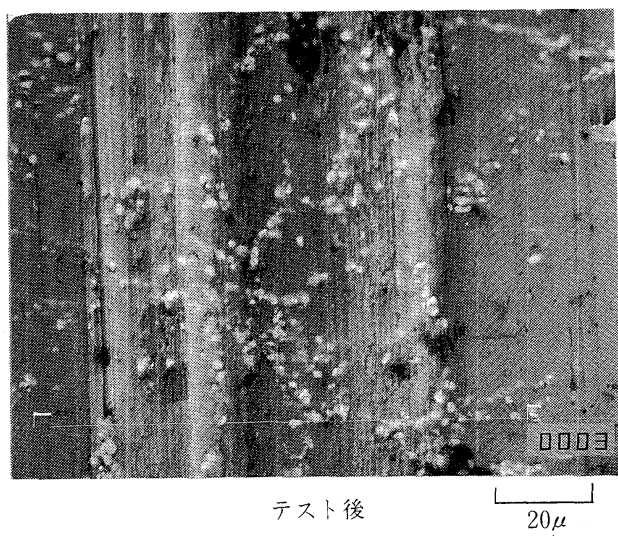

写真 4 2218のテープによる摩耗面

\section{(3) 動摩擦係数}

磁気テープとシリンダーとの動摩擦係数も重要な特性 のひとつである。摩擦係数が大きすぎるとテープの走行 が不安定になり，画像が乱れたり，場合によつてはテー プがシリンダーに貼りついてしまつたりするからであ る。

しかし動摩擦係数は磁気テープの特性としては広く調 ベられているのに対し ${ }^{5), 6)}$ ，シリンダー自体のそれはあ まり調べられていない。ここではテープの特性調査の結 果を中心に動摩擦係数をみることにしたい。

田中ら ${ }^{5)}$ はシリンダーと磁気テープとの摩擦係数を次 のようにして測定している。すなわち円筒試験片 (S45 C) に磁気テープを接触摺動させ，テープの入側と出側 の張力を测定する。動摩擦において摩擦がクーロンの法 則に従らとすれば次式が成立つ：

$$
\begin{aligned}
\frac{T_{2}-\sigma V^{2}}{T_{1}-\sigma V^{2}} & =e^{\mu \theta} \\
T_{1}, T_{2} & \text { それぞれ入側, 出側の張力 } \\
\sigma & : \text { 単位長さ当りのテープ質量 }
\end{aligned}
$$




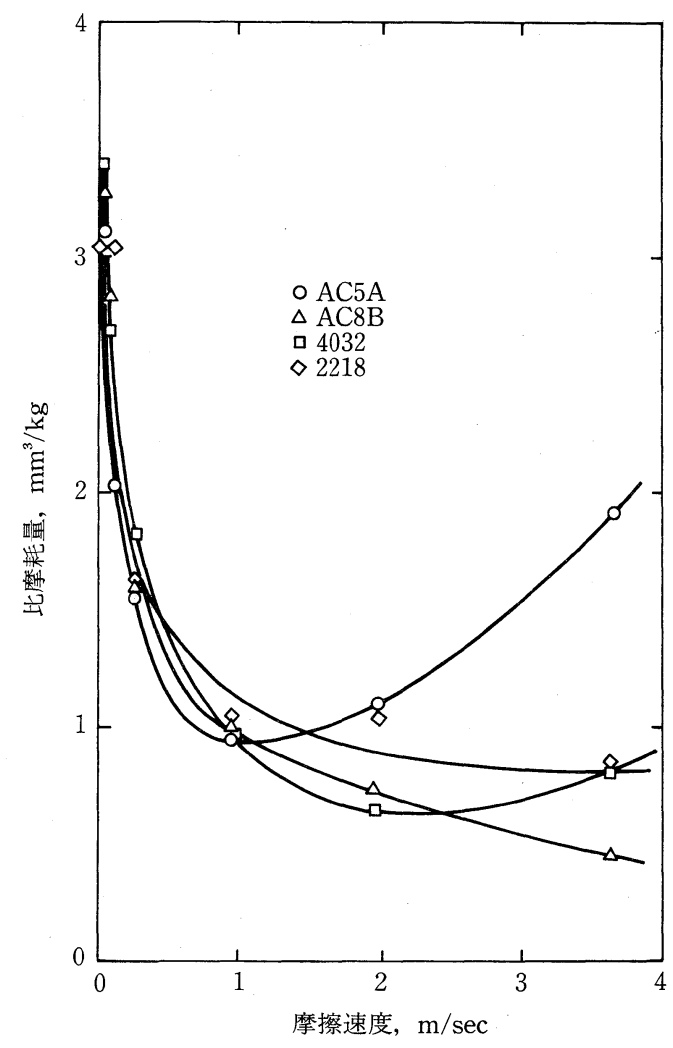

図 4 シリンダー用アルミニウム合金の耐摩耗性 ${ }^{4}$

\section{$V:$ テープと円筒との相対速度 \\ $\mu$ : 摩擦係数}

$\theta:$ テープの巻きつけ角

$\sigma V^{2}$ は遠心力による補正項であるが， $\sigma$ が小さいので $\sigma V^{2} \approx 0$ と近似される。したがつて(1)式はよく知られた オイラーの式になる :

$$
T_{2} / T_{1}=e^{\mu \theta}
$$

図 5 は田中ら ${ }^{5)}$ の測定結果を示す。図 $5($ a)は静止した 円筒面をテープが走行する場合で $\beta$ マックス方式に対応 し，(b)はテープと円筒が同じ方向に運動する場合で VH $\mathrm{S}$ 方式に対応する。どちらの場合も(2)式が成立し，オイ ラーの式によつて動摩擦係数を求めることができる。図 5 によれば(a)では摩擦係数の速度依存性が極めて小さい のに対して(b)では大きくなつている。これは(b)の場合に は円筒とテープとの相対速度が関係しているためであ り，円筒の周速が大きくなるとテープと円筒との間に空 気の潤滑膜が形成され，摩擦係数が小さくなると考えら れる5)。

摩擦係数はシリンダー表面の材質によつても，またテ ープの材質によつてもかわつてくる。

図 6 は各種のシリンダー材種についての測定結果で ある2)。この場合には硬質アルマイトの摩擦係数が大き く， $\mathrm{TiO}_{2}$ をコーティングしたもののそれが非常に小さ くなつている。ちなみに，筆者らの測定によると $2218 の$ 摩擦係数は市販の VTR テープに対して0.28程度であつ
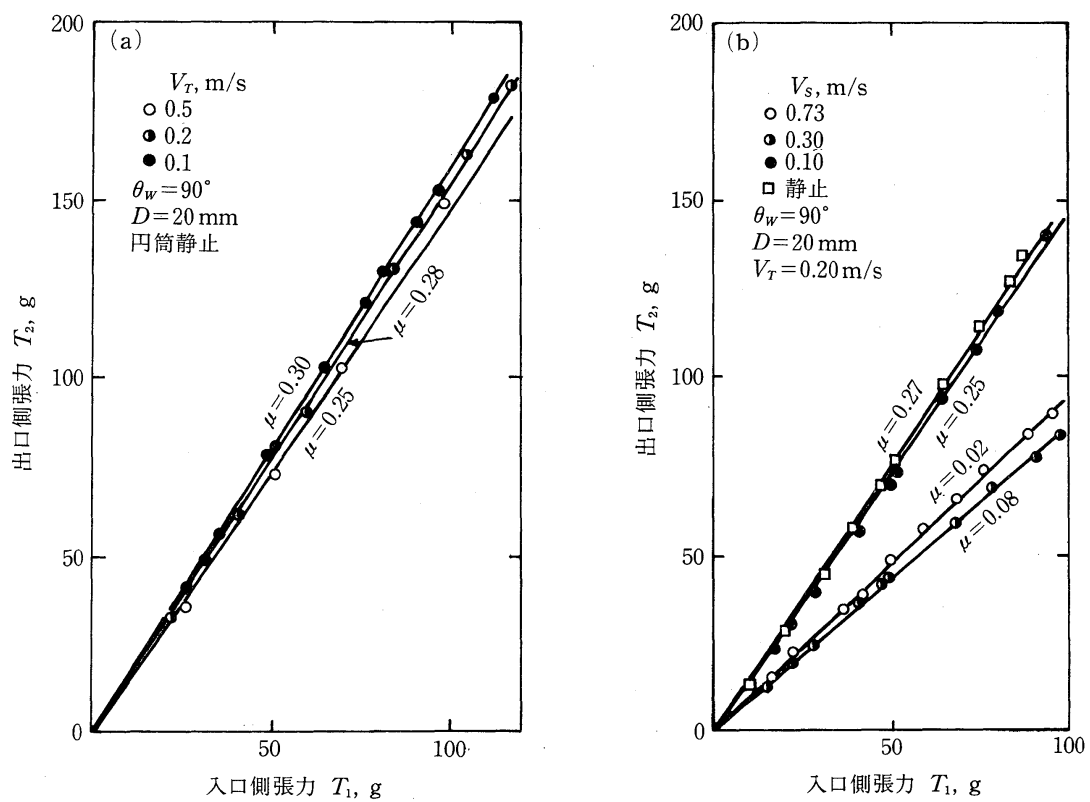

図 5 テープ走行形式と動摩擦係数

(a) 固定した円筒面上をテープが走行する場合 $(\beta$ 方式に対応)

（b） 円筒とテープが同一方向に運動する場合 (VHS 方式に対応) 
た。

図 7 は硬質クロムメッキした材料に対する摩擦係数を 柔軟性の異なる各種テープについて測定結果を 示す ${ }^{6)}$ 。 テープ材種によつて摩擦係数が異なるだけでなく，摺動 時間による変動も大きくかわることがわかる。

以上のよらに多くの因子の影響を受けるにもかかわら ず，動摩擦係数が，材料の側からほとんど調べられてい ないということは大きな問題のひとつであろら。今後, 合金組成や組織との関係で摩擦特性を明らかにすること が望まれる。

(4) 切削性

VTR シリンダーは最終的に切削加工によつて仕上げ られる。その精度はアルミニウム合金の切削加工品の中 でも第一級のレベルが要求される。たとえば，表面粗度 は $\mathrm{R}_{\max }=0.3 \sim 0.8 \mu^{7)}$ (一説に0.1 0.3 $\left.\mu\right)^{8)}$ ，偏心 $2 \sim$ $3 \mu$, 真円度 $50 \mathrm{~mm} \phi$ に対して $0.2 \mu^{8)}$ といわれている。

図 8 に, 市販のシリンダーの表面粗度の測定例を示 す。この品物では $\mathrm{R}_{\max }=0.3 \sim 0.4 \mu$ 程度であつた。 プ ロフィルには明瞭な送りマークは認められない。鏡面を 出すためにかなりバニシングのきいた切削をしているも

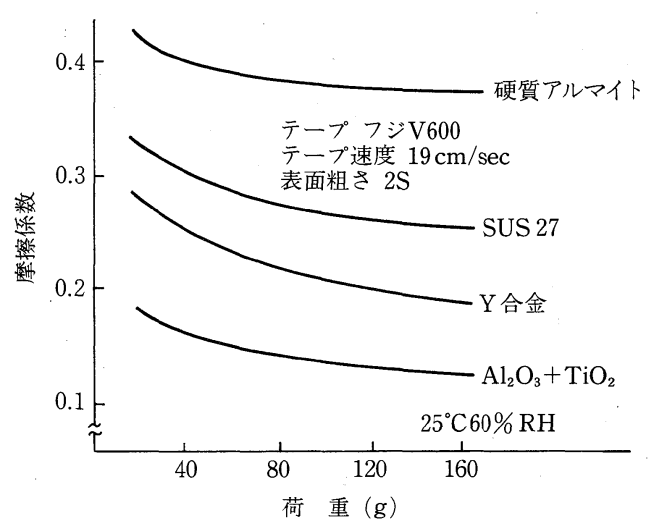

図 6 各種シリンダー材種の動摩擦係数 ${ }^{2)}$
のと考えられる。

切削は通常天然ダイヤの工具で行われる。シリンダー 材は耐摩耗性のすぐれたアルミニウム合金であるから， 工具寿命からみた切削性は必ずしも良くない。天然ダイ ヤでも一本の工具で切削できるシリンダーは1000 数千 個にすぎない?。

切削上のもらひとつの問題は穴あけ性である。写真 1 にみられるように，シリンダーには多数の穴がある。そ のため穴あけ加工はシリンダー製造の上で極めて重要な 位置を占めることになる。2218にせよ鋳物合金にせよ現 在用いられているシリンダー材の穴あけ性は必ずしもい いとは言えない。耐摩耗性を高めれば高めるほど穴あけ 性はより大きな問題となろら。

切りくず処理性も重要である。切削加工は NC 化さ

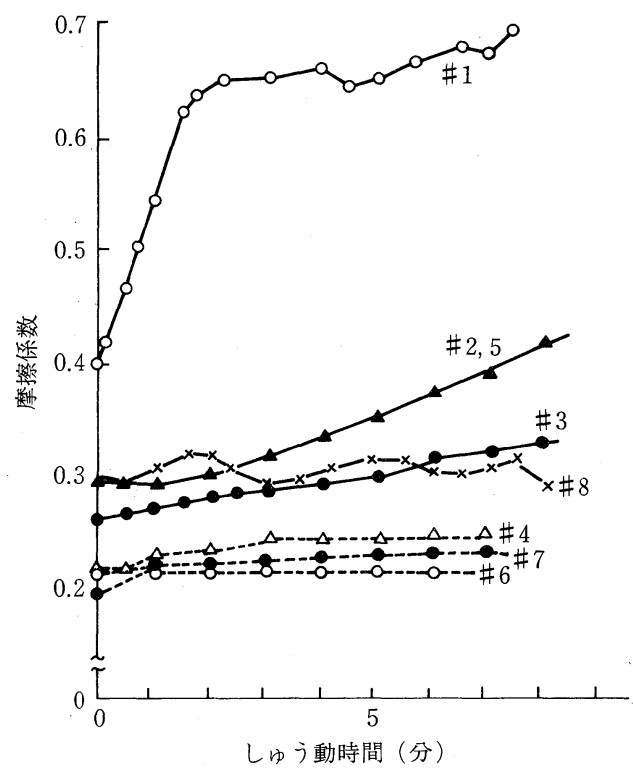

図 7 種々のテープの動摩擦係数 ${ }^{6)}$ (No はテープの種類を表す)

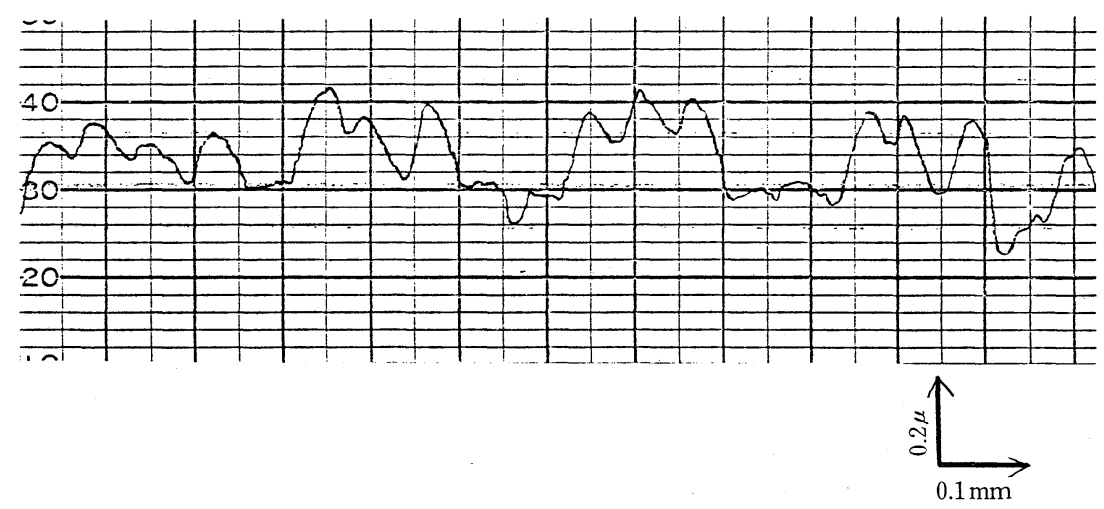

図 8 市販シリンダーの表面粗度 
れた設備で行われ，月に数万個 数十万個加工されるか ら，切りくず処理性の良否は生産性に大きな影響を及ぼ す。一般に，鋳物は切りくず分断性は良い。しかし2218 は工具形状や切削条件によつては連続した切りくずが生 成されることがある。写真 $\mathbf{5}$ は2218の押出棒を普通旋盤 で切削した場合の切りくずの例である。仕上げ切削のよ らに切りこみが小さいと切りくずは細かく分断するが， 切りこみが大きくなると連続しやすくなる。ただ，切り くずの残留延性自体は小さいので, 大量のクーラントを かけることによつて切りくずが折れることはある。

切削といら観点からすると以上述べたよらに現行のシ リンダー用アルミニウム合金はまだまだ問題が多い。他 の特性をそこなわずに切削性を高めることが今後の大き な問題である。

\section{（5）冷間鍛造性}

鋳物を除いてシリンダーは冷間鍛造によつて成形され る。したがつて冷間鍛造性の良否もシリンダー製造上重 要な問題である。

材料的な側面からすれば組織を微細化するのが泠間鍛 造性を高める道である。2218の場合では $\mathrm{Al}_{3}(\mathrm{Ni}, \mathrm{Cu})$ の晶出物を微細にする必要がある。晶出物が粗大である とそれを起点として割れが発生するからである。鋳造棒 は凝固速度が大きく, 組織が微細になるため通常の連鋳 鋳塊より有利である。

冷間鍛造性の評価方法はいくつかあるが，最も簡便な ものに落重試験法がある。これは円柱状の試験片に一定 重量の扔もりを落下させ, 変形量から変形抵抗を求める とともに，くりかえし変形によつて割れが発生寸る限界 の加工率 (変形能) をみる方法である。この方法で求め た2218の変形能と変形抵抗はそれぞれ約 $60 \%, 30 \mathrm{kgf} /$ $\mathrm{mm}^{2}$ である。これは，冷間鉛造用としてしばしば使わ れる JIS 2017 と比べ変形能がやや小さく，変形抵抗が やや大きい結果になつている。その意味で2218の冷間鍛 造性に必ずしも良くないが，実際上は大きな問題とはな つていない。

\section{5. おわりに}

VTR シリンダーに対する要求特性は多様であり，場 合によつて相反する特性が要求される。それに対して材 料的には大半が規格合金が使われているだけで，シリン ダーとして最適な材料が供給されているとは言い難い。 その意味では新しい合金を開発する余地がまだ残つてい るといえよう。

シリンダー材としての要求特性の中で不明な点が多い
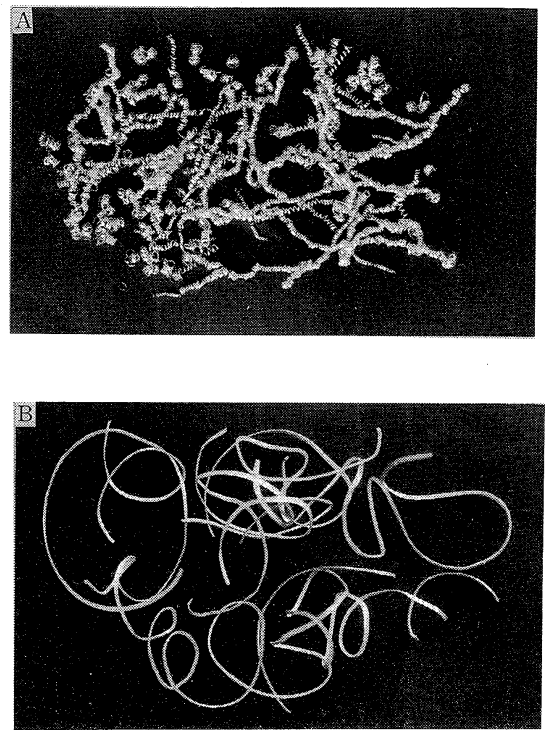

写真 5 2218の切りくず形状の例

A: 切込み $0.1 \mathrm{~mm}$, 送り $0.03 \mathrm{~mm} / \mathrm{rev}$ B : 切込み $0.5 \mathrm{~mm}$, 送り $0.1 \mathrm{~mm} / \mathrm{rev}$

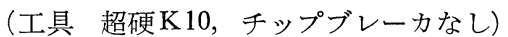

のはテープとの動摩擦特性（摩耗挙動掞よび 動摩 擦 係 数) と思われる。従来この種の試験はほとんどなされて こなかつたが，組織や合金成分に強く依存する特性と予 測されるだけに今後検討しなければならない重要な課題 である。

最後に本解説は筆者らの浅学とともに公表されたデー タの不足のため中途半端なものに終つたことをお詑び申 し上げる。

\section{参 考 文 献}

1）馬場義雄, 宇野照生：アルトピア， No. 6 (1984), 19.

2) 原 正和：ホームビデオ，日本放送出版協会 (1978).

3) Aluminum Standards and Data, 1982, The Aluminum Association.

4) 江田 弘 : 精密機械学会第102回講習会テキス 卜，「超精密加工と加工機械」，精密 機 械学 会 (1982), p. 24.

5) 田中久一郎，三好和寿 : 潤滑，19 (1974). 645.

6) 平塚広明, 花房広明, 中村孔三郎, 細川茂文 : 電子通信学会論文誌，J63-C (1980), 361.

7）日経メカニカル，1981年 8 月 3 日号，p. 48.

8）江田 弘, 貴志浩三, 上野秀雄 : 機械の研究, 35 (1983), 197. 